\title{
Mercury in the Northern Crayfish, Orconectes virilis (Hagen), in New England, USA
}

\author{
CHRIS M. PENNUTO, ${ }^{1, *}$ OKSANA P. LANE, ${ }^{2}$ DAVID C. EVERS, ${ }^{2}$ ROBERT J. TAYLOR ${ }^{3}$ \\ AND JEFF LOUKMAS ${ }^{4}$ \\ ${ }^{1}$ Department of Biology \& Center for Great Lakes Research, Buffalo State College, Buffalo, NY, USA, \\ 14222 \\ ${ }^{2}$ BioDiversity Research Institute, Gorham, ME, USA04038 \\ ${ }^{3}$ Trace Element Research Lab, Texas A \& M University, College Station, TX, USA77843 \\ ${ }^{4}$ New York State Department of Environmental Conservation, 625 Broadway, Albany, NY12233-4756
}

Accepted 4 December 2004

\begin{abstract}
Biologists and policy makers continue to seek environmental correlates of mercury bioavailability in aquatic ecosystems. In this study, we assessed the effects of drainage basin, habitat type, size class, and sex on mercury concentrations in the northern crayfish, Orconectes virilis (Hagen). Drainage basin, habitat type, and size class had significant effects on mercury concentration in crayfish tail muscle even though animals from roughly half the sites examined had mean mercury values at or below expected background levels. The low observed mercury values in crayfish tail muscle indicate a low consumptive risk. Contrary to expectations, crayfish from brooks had higher mercury concentrations than animals from other habitat types, possibly as a result of point source contamination or varying diet compositions among habitats. We suggest that crayfish represent a good indicator of mercury bioavailability in aquatic ecosystems and provide a synthesis for lower food webs. Our understanding of mercury dynamics in lower food webs has been hindered by an under appreciation of the complexity in foraging habits of macroinvertebrates. Further studies focusing on benthos with well-understood life histories and foraging behavior are essential to improve our understanding of mercury transfer and bioavailability through aquatic systems.
\end{abstract}

Keywords: trophic level; lower food webs; benthic macroinvertebrates; mercury

\section{Introduction}

Mercury pollution remains a priority contaminant concern for resource managers and policy makers. There have been numerous studies over the last 30 years investigating the health and ecological risks associated with mercury exposure (EPA, 1998). In 2002, every state except Alaska and

*To whom correspondence should be addressed:

E-mail: pennutcm@buffalostate.edu.
Wyoming issued a fish consumption advisory for at least some waters within the state and 28 states had general statewide advisories related to mercury. The total lake area under advisory restrictions continues to increase (EPA, 2002). More recently, the environmental and wildlife risks associated with mercury and methylmercury contamination have also been documented (Wren et al., 1983; Lucotte et al., 1999; Evers et al., 2003). Clearly, mercury contamination in aquatic ecosystems is a significant human and environmental 
health issue. Determining the environmental factors responsible for mercury levels observed within organisms remains elusive although several key parameters have been correlated with high mercury or methylmercury levels in fish. For example, increasing trophic position (Spry and Weiner, 1991; Jackson, 1998), body size (Scott and Armstrong, 1972; Scott, 1974; Wren et al., 1983), age (Simonin et al., 1994), dissolved organic carbon (DOC) concentration (Driscoll et al., 1995; Wiener and Spry, 1996), pH (Cope et al., 1990; Grieb et al., 1990; Haines et al., 1992), food web complexity (Futter, 1994; Wong et al., 1997; Chen et al., 2000), degree of flooding (Jackson, 1991; Johnston et al., 1991; McNicol et al., 1997), and percent of watershed with wetland habitats (Jackson, 1988; McMurty et al., 1989), have all been variously associated with mercury levels in fish or fish-eating birds and mammals.

Whereas there has been much research on mercury levels in fish, comparatively little is known about the patterns of mercury contamination in benthic macroinvertebrates. Yet, most research suggests that mercury uptake occurs primarily through consumption (Rogers, 1994), and benthic organisms comprise an important energy link in the diet of many fish species for which advisories are posted. For example, yellow perch (Perca flavescens Mitchill) remain primarily insectivorous until roughly 4 year, and the streamdwelling salmonids maintain macroinvertebratebiased diets throughout their lives. Even the large piscivores (e.g., northern pike (Esox lucius L.), walleye (Scizostedion vitreum Mitchill), smallmouth (Micropterus dolomieui), and largemouth bass (Micropterus salmoides), are opportunistic predators of macroinvertebrates, consuming crayfish, large insects, or annelids. Further, macroinvertebrates, especially aquatic insects, represent a high proportion of the diets of many of the forage fish species that are eaten by piscivores, and they are also important food items of fry and juvenile piscivores (Cooper, 1983). In addition to their importance in fish diets, benthic macroinvertebrates are critical components in ecosystem energy flow and matter cycling (e.g., Resh and Rosenberg, 1984), and contaminant release from sediments via their bioturbation activities can be significant (Matisoff and Wang, 1998). Thus, it is essential that we understand the movement of mercury through lower food webs to provide support for patterns in higher food webs.

Benthic invertebrates maintain an intimate association with lake and river sediments and sediments often harbor the highest mercury concentrations in aquatic systems (Meili, 1991; Ullrich et al., 2001). Indeed, invertebrates from mercurycontaminated lakes sometimes have very high $\mathrm{Hg}$ concentrations and concentrations that may exceed those of the top predators within the system (e.g., Parkman and Meli, 1993; Tremblay et al., 1995). Suchanek et al. (1995) reported total $\mathrm{Hg}$ concentrations in benthic oligochaetes as high as $41.7 \mu \mathrm{g} / \mathrm{g}$ and chironomid midges as high as $27.7 \mu \mathrm{g} / \mathrm{g}$ in Clear Lake, California, a site acutely contaminated by mine-effluents. However, there is not a strong relationship between sediment $\mathrm{Hg}$ concentration and invertebrate $\mathrm{Hg}$ concentration (Verta et al., 1986; Parkman and Meili, 1993; Tremblay et al., 1995). Substrate geochemistry and particle size distribution, not sediment $\mathrm{Hg}$ concentration per se, seem to correlate with $\mathrm{Hg}$ content in the benthos (Parkman and Meili, 1993; Tremblay et al., 1995). Mercury content in macroinvertebrates does not always increase with increasing body size, unlike the relationship in fish.

The relationship between invertebrate body size and mercury concentration appears to be governed by food web dynamics and the type of mercury measured. Parkman and Meili (1993) and Wong et al. (1997) found a correlation between total $\mathrm{Hg}$ concentration and predatory insect weight when compared across all taxonomic groups; however, they did not find a relationship within taxa. They suggested that life cycle duration had little to do with mercury accumulation; rather, trophic status of the invertebrate was the key factor in determining mercury levels. For example, large predatory taxa were more likely to accumulate $\mathrm{Hg}$ than small predators of a different taxon, because they were more likely to feed higher on the food chain. However, they also found lower trophic level invertebrates like detritivores and grazers with higher mercury levels than predators (Table 1), indicating that the relationship between total mercury concentration and food chain status is not always valid. Tremblay (1999) found no relationship between size and methylmercury concentrations (which averaged about $80 \%$ of the total mercury concentrations) of odonates from boreal 
Table 1. Patterns in total mercury concentration of benthic macroinvertebrates in lake and river habitats

\begin{tabular}{lll}
\hline & Habitat & Source \\
\hline $\begin{array}{l}\text { Phylogenetic effects on total mercury } \\
\text { Oligochaeta }>\text { Nematoda }>\text { Pelecypoda }>\text { Chironomidae }\end{array}$ & Lentic & Jackson (1988) \\
Heteroptera $>$ Odonata $>$ Coleoptera $>$ Trichoptera $>$ & Lentic & Tremblay and Lucotte (1997) \\
Ephemeroptera $>$ Diptera & Lentic & Wong et al. (1997) \\
Gastropoda $>$ Coleoptera $>$ Oligochaeta $>$ Chironomidae $>$ & & \\
Amphipoda $>$ Ephemeroptera $>$ Odonata $>$ & & \\
Trichoptera $>$ Hirudinea & Lotic & Hildebrand et al. (1980) \\
Megaloptera $>$ Diptera $>$ Trichoptera $>$ Decapoda & Lentic & Gorski et al. (2003) \\
Ephemeroptera $=$ Odonata $>$ Trichoptera & Lentic & Loukmas (unpubl. data) \\
Odonata $>$ Ephemeroptera $>$ Decapoda $>$ Trichoptera $>$ & & \\
Isopoda & Lotic & Loukmas (unpubl. data) \\
Diptera $>$ Megaloptera $>$ Odonata $>$ Decapoda $>$ Trichoptera & $>$ & \\
Ephemeroptera $>$ Isopoda $>$ Plecoptera & & \\
Feeding mode effects on total mercury & & Tremblay et al. (1995) \\
Predators $>$ Predator $/$ grazer $>$ Detritivore $/$ grazer $>$ Detritivore & Lentic & Mason et al. (2000) \\
Predators $>$ Herbivores $/$ Detritivores & Lotic & Parkman and Meili (1993) \\
Detritivores $>$ Predators & Lentic & Lentic \\
Predators $>$ Detritivores & Lotic & Loukmas (unpubl. data) \\
Predators $>$ Detritivores & & \\
\hline
\end{tabular}

lakes and reservoirs in Quebec. He also found an increase in $\mathrm{MeHg}$ levels with increasing food chain status among all invertebrates, suggesting that, for $\mathrm{MeHg}$ accumulation, trophic level is more important than body size, which is a concept supported by other studies (Table 2). He concluded that, because of the highly bioaccumulative nature of $\mathrm{MeHg}$, its availability to benthic invertebrates could play an important role in determining $\mathrm{MeHg}$ concentrations throughout the entire aquatic community. An understanding of the uptake, assimilation and depuration rates and pathways within macroinvertebrates is essential to unraveling the bioavailability of mercury in lower food webs.

Inorganic mercury does not easily cross the gut lining of most insects (Boudou et al., 1991), whereas methylmercury crosses readily. Both forms can pass through the gill membranes of invertebrates (e.g., Wright et al., 1991; Odin et al., 1995). This differential membrane discrimination and uptake of mercury species probably plays a

Table 2. Patterns in methylmercury content of benthic macroinvertebrates from lake and river habitats

\begin{tabular}{|c|c|c|}
\hline & Habitat & Source \\
\hline \multicolumn{3}{|l|}{ Phylogenetic effects on methylmercury } \\
\hline $\begin{array}{l}\text { Odonata }>\text { Ephemeroptera }>\text { Decapoda }>\text { Isopoda }> \\
\text { Trichoptera }\end{array}$ & Lentic & Loukmas (unpubl. data) \\
\hline $\begin{array}{l}\text { Megaloptera }>\text { Odonata }>\text { Decapoda }>\text { Trichoptera }> \\
\text { Diptera/Isopoda }>\text { Plecoptera }>\text { Ephemeroptera }\end{array}$ & Lotic & Loukmas (unpubl. data) \\
\hline $\begin{array}{l}\text { Heteroptera }>\text { Odonata }>\text { Coleoptera }>\text { Trichoptera }> \\
\text { Ephemeroptera }>\text { Diptera }\end{array}$ & Lentic & $\begin{array}{l}\text { Tremblay and Lucotte (1997), } \\
\text { Tremblay (1999) }\end{array}$ \\
\hline Diptera $>$ Trichoptera & Lentic & Weins et al. (unpubl. data) \\
\hline Odonata $>$ Trichoptera $=$ Ephemeroptera & Lentic & Gorski et al. (2003) \\
\hline \multicolumn{3}{|l|}{ Feeding mode effects on methylmercury } \\
\hline Predators $>$ Detritivores & Lentic & Loukmas (unpubl. data) \\
\hline Predators $>$ Detritivores & Lotic & Loukmas (unpubl. data) \\
\hline Predators $>$ Detritivores & Lentic & Gorski et al. (2003) \\
\hline Predators $>$ Herbivores/Detritivores & Lotic & Mason et al. (2000) \\
\hline Predators $>$ Detritivores & Lentic & Tremblay (1999) \\
\hline Predators $>$ Collector/shredders & Lentic & Hall et al. (1998) \\
\hline
\end{tabular}


significant role in preventing a general sediment $\mathrm{Hg} /$ body concentration relationship and reduces the likelihood of a biomagnification pattern for total mercury within benthic food webs. Conversely, methylmercury exhibits biomagnification within benthic food webs, but with extreme variability in the contribution of methylmercury to whole body mercury burdens among different taxa. The percent $\mathrm{MeHg}$ of $\mathrm{THg}$ in invertebrates ranges from 0 to $100 \%$, with an average across multiple orders and feeding modes of $\sim 65 \%$ (e.g., $\sim 40 \%$ in grazing mayflies and $\sim 75 \%$ in predatory odonates; Huckabee et al., 1979; Hildebrand et al., 1980; Odin et al., 1995; Tremblay et al., 1995; Tremblay and Lucotte, 1997; Fischer and Gustin, 2002). Several studies suggest benthic insects compartmentalize mercury, with high concentrations found in the gut and adsorbed to the exoskeleton (Ellwood et al., 1976; Hildebrand et al., 1980). Because of this, allowing sample organisms to clear their guts and including clean water rinses to collection protocols is recommended for $\mathrm{Hg}$ investigations in macroinvertebrates.

Mercury and methylmercury dynamics are better understood in crayfish than any other common freshwater macroinvertebrate. Crayfish are among the largest, longest-lived benthic invertebrates [2-3 years in northern climates (Martin, 1997)], are intimately associated with the substrate, have a ubiquitous distribution, and are an important food item for many organisms. Large, predatory fish species (e.g., smallmouth and largemouth bass and northern pike), multiple fish-eating bird species (e.g., herons, bitterns, loons, or kingfishers), and carnivorous, semi-aquatic mammals (e.g., raccoons, mink, and otters) consume them (Casson and Klimstra, 1983; Martin, 1997). Thus, they represent an important trophic link between benthic and water-column food webs in lakes and streams and have been suggested as excellent indicator species for mercury bioavailability studies (Verneer, 1972; Armstrong and Hamilton, 1973; Allard and Stokes, 1989; Parks, 1988; Parks et al., 1991). They exhibit high site fidelity with small home ranges (Hazlett et al., 1974), thus do not disperse as widely as fish. As omnivores, they function at multiple trophic levels simultaneously and are known to accumulate $\mathrm{Hg}$ (Armstrong and Hamilton, 1973; Parks, 1988; Allard and Stokes, 1989; Parks et al., 1991; Evers et al., 2003).
Several studies have indicated $\mathrm{Hg}$ concentrations are highest in crayfish abdominal muscle relative to other body compartments (Stinson and Eaton, 1983; Allard and Stokes, 1989; Headon et al., 1996), but the gills are also an important accumulation site (Wright et al., 1991; Simon and Boudou, 2001). Mercury concentrations increase with crayfish size (Armstrong and Hamilton, 1973; Ricon et al., 1987; Parks, 1988; Parks et al., 1991; Evers et al., 2003). Scheuhammer and Graham (1999), however, did not detect a significant body size: $\mathrm{Hg}$ concentration correlation when examining Orconectes virilis in two Ontario lakes and Lafrancois and Carlisle (2004) found no correlation between $\mathrm{THg}$ and body weight in $O$. virilis in lakes from Voyageurs National Park. Knowledge of $\mathrm{Hg}$ depuration rates and tissue specificity is essential for understanding accumulation rates and body size:concentration correlations. Headon et al. (1996) reported that crayfish assimilated $\sim$ $96 \%$ of the $\mathrm{Hg}$ in their food, but the assimilation rate differed between size classes. They suggested that small crayfish assimilated $\mathrm{Hg}$ more rapidly than large crayfish and that very little $\mathrm{Hg}$ was lost after assimilation, estimating a half-life in abdominal muscle of 3-5 years. Wright et al. (1991), however, suggested a much shorter half-life of only about 2 days for laboratory crayfish fed $\mathrm{HgCl}_{2}$ as part of their diet. Methylmercury halflives within abdominal muscle are very long, leading to bioaccumulation within individuals, and $\mathrm{MeHg}$ may account for $>75 \%$ of the total mercury found in crayfish (Headon et al., 1996). In northeastern North America, background mercury concentrations in crayfish tail muscle are expected to be $\leq 0.1 \mu \mathrm{g} / \mathrm{g}$ based on surveys of natural lakes in remote Canadian locations removed from any potential point-source contamination (Parks and Hamilton, 1987).

In this report, we summarize four years of data on the mercury content in the northern crayfish, Orconectes virilis (Hagen), from multiple habitat types and drainage basins in New England. We sought to determine if total mercury in crayfish tail muscle was predicted by drainage basin, habitat type, or sex. We also investigated size: $\mathrm{Hg}$ content relationships across a broad range of habitats to see if a general size class might represent maximum risk to $\mathrm{Hg}$ exposure. Further, we examined methyl and total mercury distribution patterns in crayfish 
tail muscle and body tissues to determine if health risks from crayfish consumption might differ between humans and wildlife, since humans tend to eat only tail muscle whereas wildlife tend to consume the entire crayfish. Based on previous work, we anticipated a significant body size:Hg concentration correlation. We also anticipated the highest mercury concentrations would be found in crayfish from reservoirs, and the lowest concentrations in crayfish from natural ponds or small brooks due to effects of water level fluctuation and the small watershed drainage area associated with low order streams. Lastly, we expected methylmercury to represent $>75 \%$ of the total mercury in crayfish and tail muscle tissue to contain greater $\mathrm{Hg}$ and $\mathrm{MeHg}$ than the remaining body parts.

\section{Materials and methods}

\section{Crayfish collections}

Northern or virile crayfish, Orconectes virilis (Hagen), were collected as part of various monitoring programs and studies conducted by BioDiversity Research Institute (BRI) in New Hampshire, Vermont, and Maine (Fig. 1). Animals were collected from brooks $(n=12)$, ponds $(n=8)$, rivers $(n=5)$, and reservoirs $(n=3)$ from four major drainage basins (Connecticut, Passumpsic, Dead, and Androscoggin Rivers) (Table 3). Brooks and rivers were sampled primarily with baited minnow traps, whereas crayfish from ponds and lake coves were obtained primarily by hand capture. All animals were collected between August and October 2000-2003 and upon capture, blotted wet weight, total length $(\mathrm{cm})$, carapace width and length $(\mathrm{cm})$, and sex were determined. We used three size classes to investigate body size:Hg concentration relationships: small (4-6 cm TL), medium $(6-8 \mathrm{~cm})$, and large (>8 cm). These lengths correspond roughly to 2,3 , and $3+$ year old animals (Armstrong and Hamilton, 1973). Crayfish were double-encased in plastic wrap, placed in ziptop plastic bags, and frozen until analysis.

Most animals from the VT and NH sampling locations were analyzed as individuals, but $\mathrm{ME}$ crayfish were generally analyzed as composite samples of 2-9 animals. Composites only included same-sized animals, thus these data were used in the size class analyses. However, sex effects were investigated without the composite samples since composites often contained mixed collections.

\section{Chemical analysis}

Analyses of $\mathrm{Hg}$ in crayfish abdominal muscle were performed at Texas A \& M University Trace Element Research Laboratory (TAMU), College Station, Texas. Tail muscle was removed from each crayfish, homogenized wet with an OMNI Mixer equipped with titanium blades, lyophilized in a Labconco Lyph Lock 12 freeze dryer, and powdered in a Spex Mixer Mill. Moisture was determined by weight loss upon freeze-drying. All VT and NH animals were analyzed individually whereas ME animals were composites of 2-9 animals of similar size. Total $\mathrm{Hg}(\mathrm{THg})$ was determined for all crayfish and methylmercury ( $\mathrm{MeHg}$ ) was determined for a subset of animals from the Connecticut River system (Moore Reservoir, $n=13$ ). Methylmercury was determined in both tail muscle and remaining body parts, exclusive of the exoskeleton, for this subset.

Samples were analyzed for $\mathrm{Hg}$ by cold-vapor atomic absorption (CVAA) using the method of Hatch and Ott (1968). Digestion procedures incorporated concentrated sulfuric and nitric acids and heating at $95{ }^{\circ} \mathrm{C}$ and used both potassium permanganate and potassium persulfate. Following digestion, excess permanganate was reduced with hydroxylamine hydrochloride and samples were diluted to final volume $(50 \mathrm{ml})$.

Mercury content of crayfish digests was measured using an LDC $\mathrm{Hg}$ Monitor equipped with a $30 \mathrm{~cm}$ cell. One $\mathrm{ml}$ aliquots of sample digests were added to a closed reaction cell where the $\mathrm{Hg}^{2+}$ was reduced to volatile $\mathrm{Hg}^{0}$ with $1 \mathrm{ml}$ of $10 \% \mathrm{w}: \mathrm{v}$ $\mathrm{SnCl}_{2}$ in $10 \% \mathrm{HCl}$. Mixing and release of $\mathrm{Hg}^{0}$ to the headspace were facilitated by vortexing the reaction cell on a Vortex Genie 2. The headspace was introduced to the CVAA absorption cell using a syringe pump set to deliver $20 \mathrm{ml}$ of deionized water to the bottom of the reaction cell. This injection approach avoided dilution of the $\mathrm{Hg}^{0}$ in the headspace that would have resulted from the use of a sweep gas. Calibration was accomplished using commercial standards (CPI) diluted as necessary with $5 \% \mathrm{HNO}_{3} / 1 \% \mathrm{HCl}$, and included a 


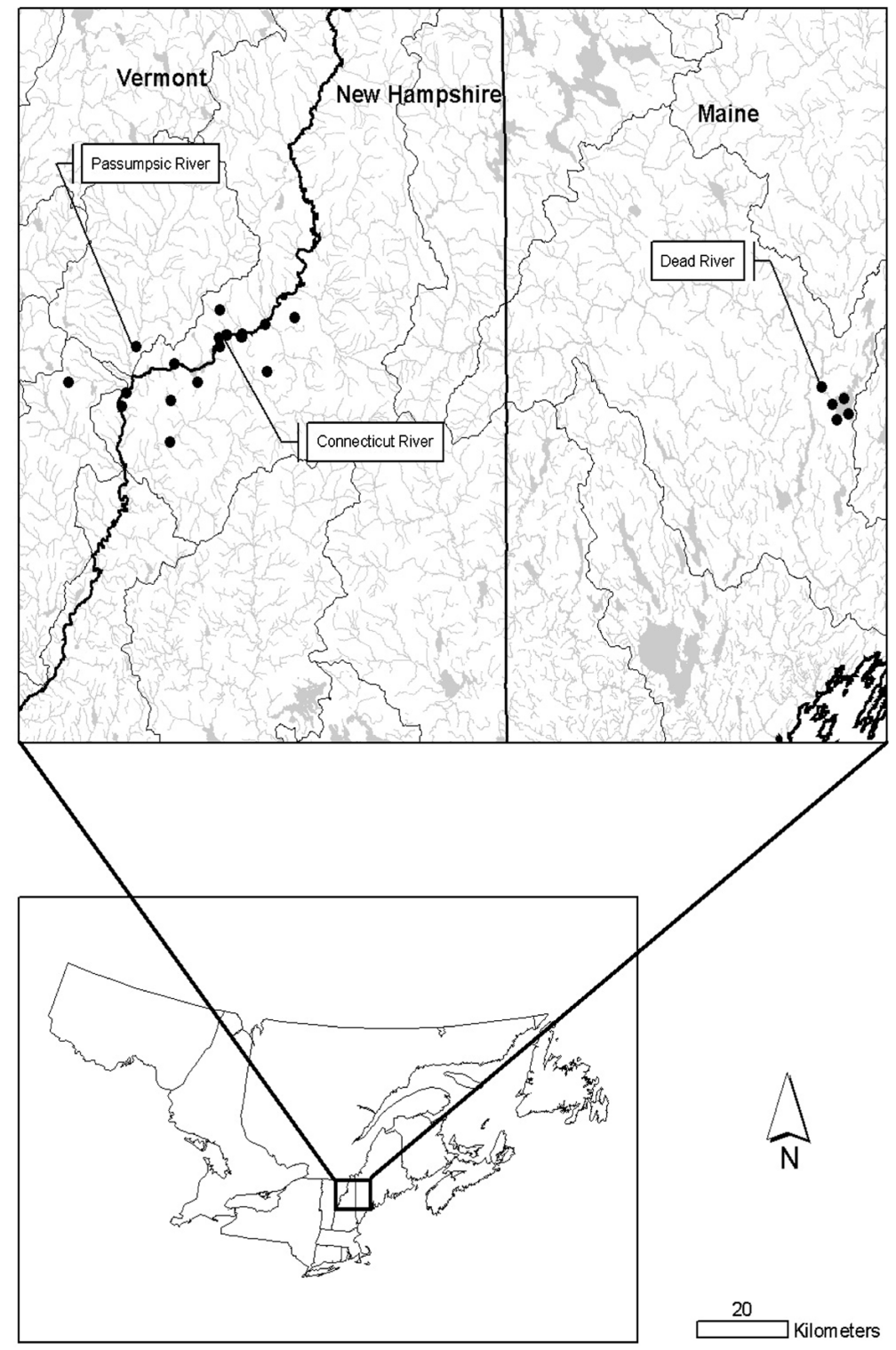

Figure 1. Orconectes virilis collection sites. Watershed boundaries are indicated.

blank and five standards that ranged from 1 to $10 \mathrm{ppb}$. The calibration line was calculated using unweighted linear regression and verified using an independent standard and a blank that were analyzed following calibration, after every 10 samples, and at the end of the analysis. $\mathrm{Hg}$ absorbance was measured using a Shimadzu CR601 integrator in peak height mode. Each batch of $\mathrm{Hg}$ samples included a method blank, spiked blank, reference material (NRCC DORM-2), duplicate sample, and spiked sample. The detection limit for total $\mathrm{Hg}$ was $0.002 \mu \mathrm{g} / \mathrm{g}$ on a wet weight basis.

A subset of 13 crayfish was analyzed for $\mathrm{MeHg}$ using the method of Wagemann et al. (1997). $\mathrm{MeHg}$ was extracted from freeze dried samples with acidic $\mathrm{KBr}$ and $\mathrm{CuSO} 4$ solutions into a 2:3 mixture of hexane:methylene chloride. Extracted $\mathrm{MeHg}$ was digested and measured by elementspecific detection of $\mathrm{Hg}$ via CVAAS, using methods similar to those described above but modified 
Table 3. Orconectes virilis collection sites

\begin{tabular}{|c|c|c|c|c|c|}
\hline Drainage basin & Sampling site & State & $\begin{array}{l}\text { Habitat } \\
\text { type }\end{array}$ & $\begin{array}{l}\text { Number of } \\
\text { O. virilis } \\
\text { analyzed }^{\text {a }}\end{array}$ & $\begin{array}{l}\text { Mean THg } \\
\text { concentration } \\
(\mu \mathrm{g} / \mathrm{g}, \mathrm{ww})\end{array}$ \\
\hline Amonoosuk & Amonoosuk & NH & 1 & 2 & 0.044 \\
\hline Androscoggin & Androscoggin River & ME & 1 & $5^{\mathrm{a}}$ & 0.120 \\
\hline \multirow[t]{16}{*}{ Connecticut } & Carpenter Brook & VT & 4 & 1 & 0.216 \\
\hline & Comerford Reservoir & NH & 3 & 12 & 0.101 \\
\hline & Connecticut River & $\mathrm{NH}$ & 1 & 14 & 0.163 \\
\hline & Cow Brook & VT & 4 & 2 & 0.094 \\
\hline & Cutting Brook & VT & 4 & 10 & 0.099 \\
\hline & Dodge Pond & NH & 2 & 2 & 0.038 \\
\hline & Forest Lake & NH & 2 & 2 & 0.044 \\
\hline & Martin Meadow Pond & NH & 2 & 7 & 0.034 \\
\hline & Martin’s Pond & VT & 2 & 10 & 0.023 \\
\hline & McIndoe Reservoir & NH & 3 & 11 & 0.089 \\
\hline & Miles Brook & VT & 4 & 10 & 0.155 \\
\hline & Miles Pond & $\mathrm{NH}$ & 2 & 1 & 0.122 \\
\hline & Moore Reservoir & $\mathrm{NH}$ & 3 & 15 & 0.186 \\
\hline & Mulliken Brook & NH & 4 & 11 & 0.070 \\
\hline & Roaring Brook & VT & 4 & 11 & 0.188 \\
\hline & Un-named Brook & NH & 4 & 4 & 0.091 \\
\hline \multirow[t]{9}{*}{ Dead } & Androscoggin Lake & ME & 2 & $9^{\mathrm{a}}$ & 0.119 \\
\hline & Bear brook & ME & 4 & $2^{\mathrm{a}}$ & 0.164 \\
\hline & Bog Brook & ME & 4 & $1^{\mathrm{a}}$ & 0.045 \\
\hline & Cove Road Brook & ME & 4 & $3^{\mathrm{a}}$ & 0.550 \\
\hline & Dead River & ME & 1 & $11^{\mathrm{a}}$ & 0.218 \\
\hline & Decoster's Stream & ME & 4 & $2^{\mathrm{a}}$ & 0.186 \\
\hline & Gould Brook & ME & 4 & $8^{\mathrm{a}}$ & 0.161 \\
\hline & Mill Pond & ME & 2 & $4^{\mathrm{a}}$ & 0.063 \\
\hline & Pocasset Lake & ME & 2 & $6^{\mathrm{a}}$ & 0.091 \\
\hline Passumpsic & Passumpsic River & VT & 1 & 6 & 0.044 \\
\hline
\end{tabular}

${ }^{\text {a }}$ Indicates composite sample of 2-9 individuals.

as necessary for reduced sample sizes. $\mathrm{MeHg}$ QC samples were similar to those included for total $\mathrm{Hg}$ analysis, with the difference that standards and spikes were prepared from $\mathrm{CH}_{3} \mathrm{HgCl}$ (Johnson Matthey). MeHg is certified in DORM-2 at $4.47 \mu \mathrm{g} / \mathrm{g}$. The detection limit for $\mathrm{MeHg}$ was $0.0008 \mu \mathrm{g} / \mathrm{g}$ on a wet weight basis.

\section{Statistical procedures}

All statistical analyses were carried out on logtransformed THg data to meet variance assumptions. We used a MANOVA to determine whether drainage basin $(n=4)$, habitat type $(n=4)$, or size class $(n=3)$ provided significant information to explain the mercury concentration in crayfish tail muscle. A one-way ANOVA followed by Tukey's HSD post-hoc multiple comparison test was applied to all variables with significant effects on mercury concentration. Compartmentalization of mercury (tail muscle versus body) and percent methylmercury in the two body regions was assessed with separate $t$-tests and the crayfish size:Hg concentration relationship was examined using linear regression. All analyses were performed using Statistix ${ }^{\odot}$ for Windows (Analytic Software, Tallahassee, FL) with $\alpha=0.05$.

\section{Results}

Crayfish were collected from 28 sites and total mercury in tail muscle was determined for 182 samples among all sites, 41 of which were composite samples (Table 3 ). There was no significant difference in mean weight of animals among the four drainage basins $\left(\mathrm{F}_{3,178}=0.44 ; p=0.722\right)$ and length explained over $91 \%$ of the variance in body 
mass (Fig. 2). Crayfish from the Passumpsic River basin grew more rapidly than crayfish from the remaining basins as indicated by the much steeper regression slope $(b)$ in the weight/length plots ( $b=0.608,0.199,0.216$, 0.221 for Passumpsic, Androscoggin, Connecticut, and Dead River basins, respectively). Quality assurance and quality control results for both total and methylmercury were well within accepted levels, generally resulting in \% recoveries in spiked samples between 93 and $103 \%$ and RPD under 10\% (Table 4).

There was a significant relationship between $O$. virilis length $(\mathrm{cm})$ and $\mathrm{THg}$ concentration in tail muscle $\left(\mathrm{F}_{1,180}=18.93 ; p \ll 0.001\right)$, but length only explained a small proportion of the observed variance in mercury $\left(R^{2}=0.095\right.$; Fig. 3$)$. Even though mercury concentration in tail muscle was variable across sites, there were significant drainage basin, habitat type, and size class effects on mercury concentration in crayfish (all $p<0.05$ ). There was not a significant sex effect on mercury concentration $(p>0.05)$. One-way ANOVAs and post-hoc Tukey tests confirmed the lack of a sex effect on mercury content in crayfish and significance for remaining effects (Table 5, Fig. 4). Crayfish from the Dead River drainage basin in Maine contained significantly higher mercury than crayfish from the Connecticut and Passumpsic drainages, but were not significantly different from crayfish in the Androscoggin (Fig. 4). Thus, the eastern most sites had mercury levels higher than the western sites. Among habitat types, crayfish from natural ponds had significantly less mercury than crayfish from streams, rivers, or reservoirs (Fig. 4), regardless of drainage basin. The largest crayfish size class had significantly higher total mercury content than the medium and the small size classes (Fig. 4).

Table 4. Mean percent recovery (spiked blanks, spiked samples, and SRM's) and mean relative percent difference (RPD; duplicate samples) results for total and methylmercury QA/QC testing

\begin{tabular}{lllll}
\hline & $\begin{array}{l}\text { Spiked } \\
\text { blanks }\end{array}$ & SRM & $\begin{array}{l}\text { Duplicate } \\
\text { samples }\end{array}$ & $\begin{array}{l}\text { Spiked } \\
\text { samples }\end{array}$ \\
\hline $\begin{array}{l}\text { Total mercury } \\
\text { Mean }\end{array}$ & 102.5 & 95.5 & 8.1 & 101 \\
$\begin{array}{l}\text { Standard error } \\
\text { Sample size }\end{array}$ & 0.96 & 1.04 & 1.86 & 2.44 \\
$\begin{array}{l}\text { Maximum } \\
\text { Minimum }\end{array}$ & 13 & 14 & 14 & 13 \\
$\begin{array}{l}\text { Methylmercury } \\
\text { Mean }\end{array}$ & 95 & 100 & 18 & 108 \\
$\begin{array}{l}\text { Standard error } \\
\text { Sample size }\end{array}$ & 1 & 88 & 0 & 76 \\
Maximum & & 96.5 & 3 & \\
Minimum & & 0.50 & & 93 \\
\hline
\end{tabular}

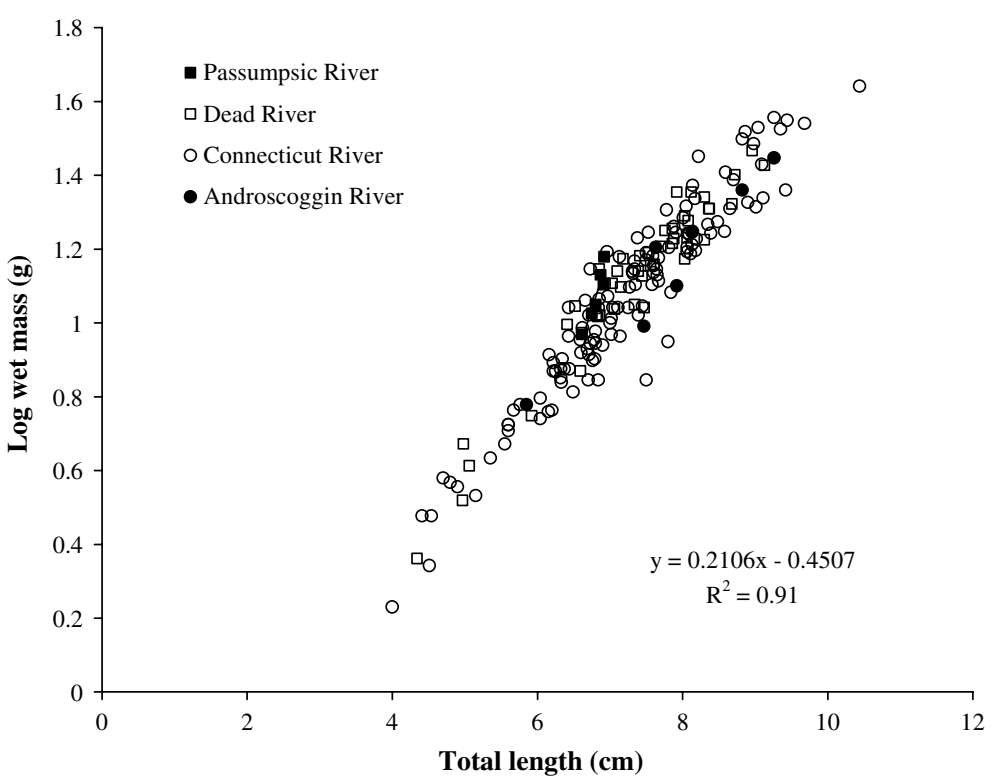

Figure 2. Length/mass relationship for crayfish collected in four drainage basins in New England. 


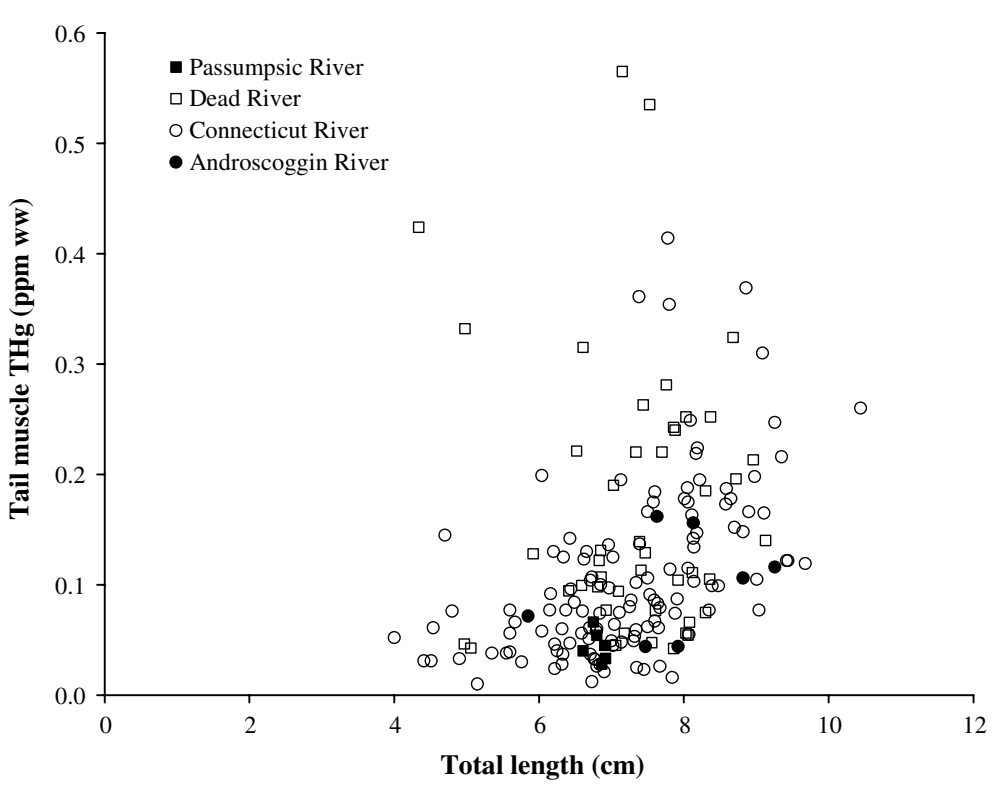

Figure 3. Scatterplot of tail muscle mercury content $(\mu \mathrm{g} / \mathrm{g} \mathrm{ww})$ as a function of crayfish length from four New England drainage basins.

Table 5. Results of one-way ANOVAs determining effects on tail $\mathrm{Hg}$ concentration $(\mu \mathrm{g} / \mathrm{g}$, ww) in crayfish (Orconectes virilis) across New England

\begin{tabular}{llrr}
\hline & df & F & P \\
\hline Drainage basin & 3.178 & 7.34 & $<0.001$ \\
Habitat type & 3.178 & 11.76 & $\ll 0.001$ \\
Size category & 2.179 & 9.19 & $<0.001$ \\
Sex & 1.143 & 0.01 & n.s. \\
\hline
\end{tabular}

Drainage basin, habitat type, and size categories identified in Methods. Data include site composite samples for drainage basin, habitat type, and size categories, but not sex.

The $\%$ methylmercury in tail muscle tissue was not significantly different from the $\%$ methylmercury in the remaining body parts $(t=0.64$, $\mathrm{df}=24, p=0.528$ ), nor was there any difference in the concentration of $\mathrm{MeHg}$ in the two body regions ( $t=1.39, \mathrm{df}=24, p=0.176$; Fig. 5). $\mathrm{MeHg}$ averaged $88 \%$ of the total mercury in crayfish and did not show any correlation with crayfish size $(r=0.455, \mathrm{df}=11, p=0.159)$. Tail muscle THg $(\mu \mathrm{g} /$ $\mathrm{g}$ ww) was not significantly different from the remaining body $\mathrm{THg}$ concentration $(t=1.31$, df $=24, p=0.202$; Fig. 5).

\section{Discussion}

Mercury concentrations exhibited high variability in the crayfish Orconectes virilis across three New
England states, and half of the sites (14 of 28 or $50 \%$ ) had representative animals with mercury levels at or above expected background concentrations $(\leq 0.1 \mu \mathrm{g} / \mathrm{g}$; Parks and Hamilton, 1987). This background concentration represents mercury levels detected in crayfish from isolated water bodies located in pristine habitats of Canada with geology and vegetation similar to our study areas. Three of the four variables examined had significant effects on mercury concentration in crayfish tail muscle: drainage basin, habitat type, and crayfish size class. The remaining variable, sex, had no significant effect on mercury concentration in crayfish. Whereas other studies have found strong correlations between water chemistry variables and mercury content in organisms (e.g., pH and DOC; Allard and Stokes, 1989; Cope et al., 1990; Gorski et al., 


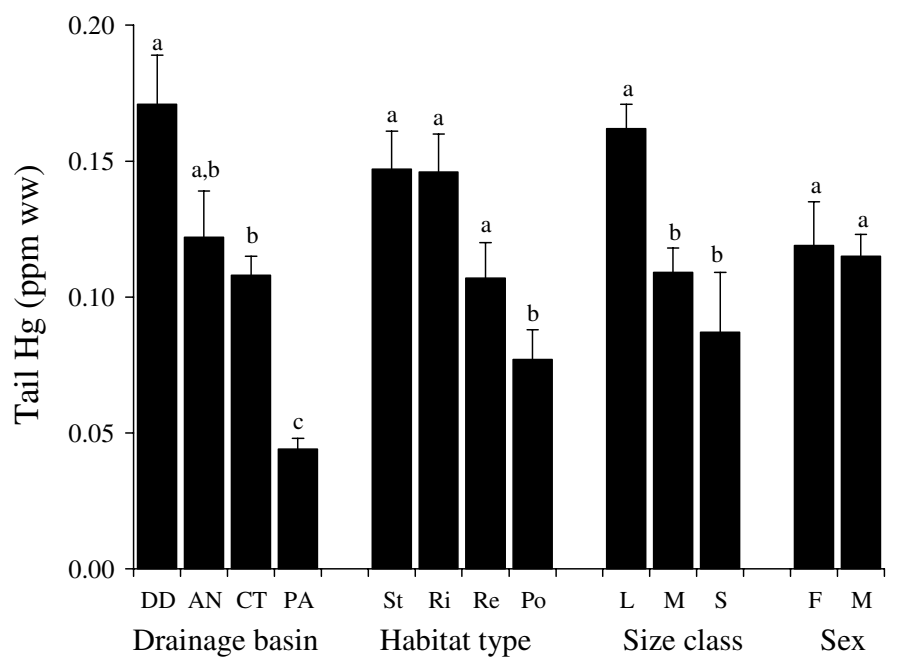

Figure 4. Tukey LSD post-hoc results for drainage basin, habitat type, and size class effects on mercury concentration in crayfish. Same letters within each main effect are not significantly different from each other at $p<0.05$. For drainage basins, DD $=\mathrm{Dead}$ River, Maine; $\mathrm{AN}=$ Androscoggin River, Maine; $\mathrm{CT}=$ Connecticut River, Vermont/New Hampshire; PA = Passumpsic River, Vermont. For habitat type, $\mathrm{St}=$ stream or brook; $\mathrm{Ri}=$ river; $\mathrm{Re}=$ reservoir; Po $=$ pond/natural lake. For size class, $\mathrm{L}=$ large $(\geq 8 \mathrm{~cm}) ; \mathrm{M}=$ medium $(68 \mathrm{~cm}) ; \mathrm{S}=$ small $(4-6 \mathrm{~cm})$. Bars represent $1 \mathrm{SE}$.

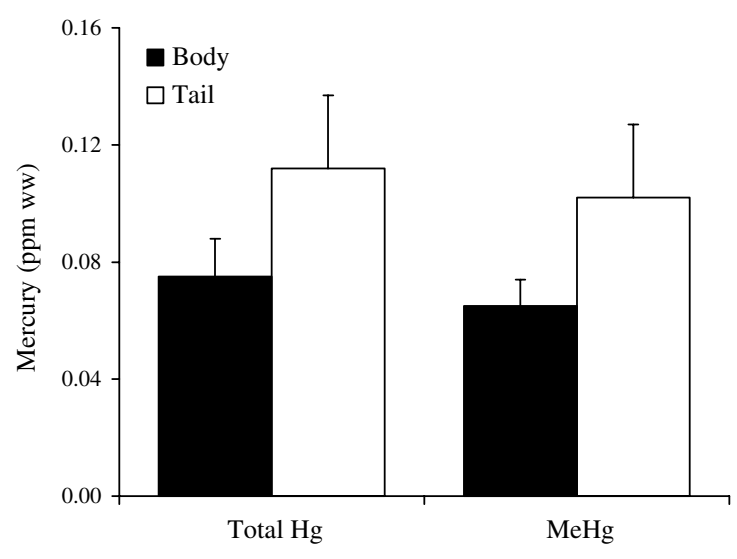

Figure 5. Total and methyl mercury concentration in tail muscle and the remaining body for the crayfish Orconectes virilis from Moore Reservoir, VT/NH.

2003), we focused on larger-scale variables across a large geographic area.

In Maine, $70 \%$ (7 of 10) of the sample sites exceeded the expected background level, but only a single site had mercury levels exceeding $0.3 \mu \mathrm{g} / \mathrm{g}$, the lowest observed effects level (LOEL) concentration for reproductive impairment in Common Loons (Gavia immer) (Barr, 1986). The mercury concentration in crayfish from this site (Cove Road Brook) averaged $0.55 \mu \mathrm{g} / \mathrm{g}(n=3$ composite analyses), a value well above the $0.1 \mu \mathrm{g} / \mathrm{g}$ expected background level. In NH and VT, $50 \%$ of the sites exceeded background expectations, but no sites exceeded the $0.3 \mu \mathrm{g} / \mathrm{g}$ LOEL concentration for Common Loons. These data indicate that crayfish in three of four drainage systems would not pose significant risks to foraging wildlife and that $O$. virilis serves as a good site indicator for $\mathrm{Hg}$, identifying a potential point-source contamination site at Cove Road Brook. Since drainage basins, by definition, have hydrologic connectivity, it is not surprising to observe a significant drainage effect on mercury content as within drainage concentrations should be more similar than between drainage concentrations, especially over the rather short geographic distance sampled during this study. Even so, there was a suggestion of a west-to-east increase in $\mathrm{Hg}$ concentration similar to that detected by Evers et al. (1998) for mercury concentrations in loons across a much larger geographic area of northern North America. Lafrancois and Carlisle's (2004) recent finding of a low average mercury level in $O$. virilis of Voyageur National Park $(0.06 \mu \mathrm{g} / \mathrm{g})$ also supports an easterly increase in crayfish mercury content. Our sites did not differ appreciably in elevation or geology (based on surficial geology maps), thus landscape position and watershed geochemistry 
likely do not account for the spatial pattern of increased mercury.

The pattern of mercury concentration among habitat types differed from our expectation that reservoir crayfish would contain the highest mercury and stream-dwelling or pond crayfish would contain the lowest. Although crayfish from ponds and natural lakes contained the lowest mercury, stream and river animals exhibited higher levels than we expected. We anticipated that the low watershed area associated with small order streams would reduce the residence time of water within a basin, thus reducing time available for mercury accumulation or methylation. Perhaps the intimate association between small brooks and their surrounding forest soils, prior to significant dilution from larger water bodies, affects mercury retention in these systems (Allan, 1995). Alternatively, Hogger (1988) suggests pond-dwelling crayfish may be more herbivorous than lotic crayfish. If pond-dwelling $O$. virilis are more herbivorous than stream-dwellers, they might be expected to have lower $\mathrm{Hg}$ levels since plant tissue is low in $\mathrm{Hg}$ relative to animal tissue. Mercury isotopic analyses have been used to detect the sources of mercury for sediments and food webs in Lake Ontario (Jackson, 2001), and would prove valuable in determining the dietary $\mathrm{Hg}$ source (animal or vegetable matter) for animals from different habitat types.

Large crayfish ( $\geq 8 \mathrm{~cm} T L)$, regardless of habitat type or drainage, had higher total mercury concentrations than medium or small crayfish, indicating $\mathrm{Hg}$ accumulation occurs and that depuration rates are very low. This observation supports the conclusion of Headon et al. (1996) that $\mathrm{Hg}$ half-life in crayfish muscle is very long (3-5 years). Methylmercury represented nearly $90 \%$ of total mercury in all the crayfish examined, in agreement with our expectation and work of Lafrancois and Carlisle (2004) (88\% MeHg in $O$. virilis from VNP). However, we did not find a significant correlation between $\% \mathrm{MeHg}$ and crayfish size for animals from Moore Reservoir (the only site where methylmercury was measured), even though this subset of animals spanned nearly the entire size range across the whole study area. Additionally, the mercury concentration (both $\mathrm{MeHg}$ and $\mathrm{THg}$ ) in tail muscle did not differ from the remaining body parts. This observation is contrary to the findings of several others (Stinson and Eaton, 1983; Allard and Stokes, 1989; Headon et al., 1996). Greater understanding of the foraging behavior of these animals may help explain the observed patterns. Crayfish diet composition often shifts from a dominance of animal matter in juveniles to plant matter in adults $\geq 2.5$ year old (Goddard, 1988). Given the apparent long half-life of $\mathrm{MeHg}$ in these animals, if juveniles consume a larger fraction of animal matter than adults and if animal matter contains higher methylmercury content than plant material (Watras et al., 1998), then $\mathrm{MeHg}$ concentrations should reach high values early and remain stable with age or show only a slight increase since animal matter is not completely eliminated from the diet of mature crayfish. We recommend that further studies examine methylmercury and diet composition across a range of crayfish sizes within a system to evaluate this expectation.

The lack of a significant compartmental difference in both $\mathrm{MeHg}$ and $\mathrm{THg}$ was surprising since other studies have shown large differences in mercury concentrations in multiple body parts (Stinson and Eaton, 1983; Allard and Stokes, 1989; Wright et al., 1991; Headon et al., 1996; Simon and Boudou, 2001). Potentially, our decision to quantify $\mathrm{Hg}$ in just two body compartments (i.e., tail muscle vs rest of the body, exclusive of the exoskeleton) masked some of the variability. For example, gill tissue is a significant $\mathrm{Hg}$ accumulation site (Simon and Boudou, 2001) that was analyzed with the 'body' fraction in our study, potentially elevating observed body burdens. The similarity in body and tail muscle mercury concentrations suggests wildlife dietary exposure per unit tissue mass consumed is roughly the same as the dietary exposure experienced by humans consuming $O$. virilis since there was no apparent compartmentalization of mercury. Our findings also indicate that tail muscle concentrations are a good index of whole animal mercury and methylmercury, providing a good parameter for mass balance investigations within lower food webs.

\section{Conclusions}

As a polytrophic consumer, crayfish are in a unique position in benthic aquatic food webs, 
occupying a large range of feeding levels at the same time, from detritivore to carnivore (Hogger, 1988; Creed, 1994). By consuming detritus, macrophytes, and animal tissue, $\mathrm{Hg}$ concentrations in crayfish are likely directly dependent on abiotic and microbial processes, as well as aquatic food web dynamics. Their generic feeding habits and desirability as a food item make crayfish an important link in the transfer of mercury in aquatic systems. Their high site fidelity, relatively long life, ubiquitous distribution throughout the northeastern United States and southeastern Canada, and consistently high percent $\mathrm{MeHg}$ enhance the value of $O$. virilis as an indicator of local mercury bioavailability. However, our unexpected results regarding habitat-, body size-, and compartmentalization-Hg relationships illustrate the need to further our understanding of mercury movement in aquatic food webs.

The details of mercury movement through lower trophic webs have been underappreciated until recently. The large and often dominant biomass that benthic macroinvertebrates represent in aquatic systems, plus their essential role as prey for higher consumers, suggests they will be critical to a complete understanding of mercury transfer in freshwaters. The large variability in functional feeding modes with major invertebrate groups precludes finding strong phylogenetic relationships between mercury content and benthic macroinvertebrates. However, a focus on individual taxa with well-documented life history and feeding behavior may prove valuable in generating patterns of mercury contamination within the benthos. For example, the Odonata and Belostomatidae represent some of the largest insect predators in freshwater lakes and ponds. The Odonata (all Families) are obligatory macrophagous predators consuming their prey whole, whereas the Belostomatidae are obligatory, fluid sucking predators within the Hemiptera. The odonates should receive a larger mass of mercury per prey consumed since they eat the entire prey item. The belostomatids, by consuming the liquefied internal parts of their prey, should not receive any mercury adsorbed to the exoskeleton nor any mercury adsorbed to detritus within the prey's gut, a significant mercury compartment in benthic organisms (Ellwood et al., 1976; Hildebrand et al., 1980). However, belostomatid diets should be higher quality diets with lower $\mathrm{C}: \mathrm{N}: \mathrm{P}$ ratios since chitin is a nitrogen and phosphorous-deficient biomolecule (Sterner and Elser, 2002). The diet mass also is not diluted by the disproportionately large mass of the exoskeleton of insect prey. Together, these diet qualities should make their ingested mercury concentration higher per prey mass consumed. Future research focusing on mercury concentrations and bioaccumulation in benthic consumers with clearly detailed dietary habits, like odonates and belostomatids, will shed light on mercury transfer pathways and accumulation in lower food webs of aquatic ecosystems.

\section{References}

Allan, J.D. (1995). Stream Ecology Structure and Function of Running Waters. Chapman and Hall, London England, 388-233 pp.

Allard, M. and Stokes, P.M. (1989). Mercury in crayfish species from thirteen Ontario lakes in relation to water chemistry and smallmouth bass (Micropterus dolomieui) mercury. Can. J. Fish. Aquat. Sci. 46, 1040-6.

Armstrong, F.A.J. and Hamilton, A.L. (1973). Trace metals and metal-organic interaction in natural waters. pp. 131-156. Ann Arbor, MI: Ann Arbor Science Publishers, Inc.

Barr, J.F. (1986). Population dynamics of the Common Loon (Gavia immer) associated with mercury-contaminated waters in northern Ontario. Canadian Wildlife Service Occasional Paper No. 56. Ottawa, Canada. 25 pp.

Boudou, A., Delnomdedieu, M., Georgescauld, D., Ribeyre, F. and Sauter, E. (1991). Fundamental roles of biological barriers in mercury accumulation and transfer in freshwater ecosystems (analysis at organism, organ, cell amd molecular levels). Water Air Soil Pollut. 56, 807-22.

Casson, J.E. and Klimstra, W.D. (1983). Winter foods of mink in southern Illinois. Trans. Ill. State Acad. Sci. 76, 281-92.

Chen, C.Y., Stemberger, R.S., Klaue, B., Blum, J., Pickhardt, P.C. and Folt, C.L. (2000). Accumulation of heavy metals in food web components across a gradient of lakes. Limnol. Oceanogr. 45, 1525-36.

Cooper, E.L. (1983). Fishes of Pennsylvania and the Northeastern United States. The Pennsylvania State University Press, University Park and London 243 pp.

Cope, W.G., Wiener, J.G. and Rada, R.G. (1990). Mercury accumulation in yellow perch in Wisconsin seepage lakes: relation to lake characteristics. Environ. Toxicol. Chem. 9, 931-40.

Creed, R.P. Jr. (1994). Direct and indirect effects of crayfish grazing in a stream community. Ecology 75, 2091-103.

Driscoll, C.T., Blette, V., Yan, C., Schofield, C.L., Munson, R. and Holsapple, J. (1995). The role of dissolved organic carbon in the chemistry and bioavailability of mercury in remote Adirondak lakes. Water Air Soil Pollut. 80, 499-508. 
Elwood, J.W., Hildebrand, S.G. and Beauchamp, J.J. (1976). Contribution of gut contents to the concentration and body burden of elements in Tipula spp. from a spring fed spring. J. Fish. Res. Board Can. 33, 1930-8.

EPA (1998). Mercury Study Report to Congress. EPA-452/R97-003. USEPA. Office of Air Quality Planning and Standards, Washington D.C

EPA. (2002). Website: http://www.epa.gov/waterscience/presentations/fish/maps_ graphics_files/frame.htm. (viewed February 3, 2004)

Evers, D.C., Lane, O.P., Albano, D. and Pennuto, C.M. (2003). Investigation into mercury exposure and risk to wildlife for the 15-Mile Falls Project, 2000. Report BRI2003-08 submitted to USGen NE. BioDiversity Research Institute, Falmouth, ME 40.

Evers, D.C., Kaplan, J.D., Meyer, W.M., Reaman, P.S., Braselton, W.E., Major, A., Burgess, N. and Scheuhammer, A.M. (1998). Geographic trend in mercury measured in common loon feathers and blood. Environ. Toxicol. Chem. 17, 173-83.

Fischer, P. and Gustin, M.S. (2002). Influence of natural sources on mercury in water, sediment and aquatic biota in seven tributary streams of the East Fork of the Upper Carson River, California. Can. J. Fish. Aquat. Sci. 133, 28395.

Futter, M.N. (1994). Pelagic food-web structure influences probability of mercury contamination in lake trout (Salvelinus namaycush). Sci. Total Environ. 145, 7-12.

Goddard, J.S. (1988). Food and feeding. In D.M. Holdrich and R.S. Lowery (eds). Freshwater Crayfish: Biology, Management, and Exploitation, pp. 145-66. Portland, OR, USA: Timber Press.

Gorski, P.R., Cleckner, L.B., Hurley, J.P., Sierszen, M.E. and Armstrong, D.E. (2003). Factors affecting enhanced mercury bioaccumulation in inland lakes of Isle Royale National Park, USA. Sci. Total Environ. 304, 327-48.

Grieb, T.M., Driscoll, C.T., Gloss, S.P., Schofield, C.L., Bowie, G.L. and Porcella, D.B. (1990). Factors affecting mercury accumulation in fish in the upper Michigan peninsula. Environ. Toxicol. Chem. 9, 919-30.

Haines, T.A., Komov, V.A. and Jagoe, C.H. (1992). Lake acidity and mercury content in fish in Darwin National Reserve, Russia. Environ. Pollut. 78, 107-12.

Hall, B.D., Rosenberg, D.M. and Weins, A.P. (1998). Methyl mercury in aquatic insects from an experimental reservoir. Can. J. Fish. Aquat. Sci. 55, 2036-47.

Hatch, W.R. and Ott, W.L. (1968). Determination of submicrogram quantities of mercury by atomic absorption spectrophotometry. Anal. Chem. 40, 2085-7.

Hazlett, B., Rittschof, D. and Rubenstein, D. (1974). Behavioral biology of the crayfish Orconectes virilis L.: home range. Amer. Midl. Nat. 92, 301-19.

Headon, C.M., Hall, R.J. and Mierle, G. (1996). Dynamics of radiolabelled methylmercury in crayfish (Orconectes virilis). Can. J. Fish Aquat. Sci. 53, 2862-9.

Hildebrand, S.G., Rodney, H., Strand, J. and Huckabee, W. (1980). Mercury accumulation in fish and invertebrates of the North Fork Holston River, Virginia and Tennessee. $J$. Environ. Qual. 9, 393-400.
Hogger, J.B. (1988). Ecology, population biology and behavior. In D.M. Heldich and R.S. Lowery (eds). Freshwater Crayfish: Biology, Management and Exploitation, pp. 114 44. Portland, OR, USA: Timber Press.

Huckabee, J.W., Elwood, J.W. and Hildebrand, S.G. (1979). Accumulation of mercury in freshwater biota. In J.O. Nriagu (eds). The biogeochemistry of mercury in the environment, pp. 277-302. Amsterdam, New York, Oxford: Elsevire/North-Holland Biomedical Press.

Jackson, T.A. (1988). Accumulation of mercury by plankton and benthic invertebrates in riverine lakes of Northern Manitoba (Canada): importance of regionally and seasonally varying environmental factors. Can. J. Fish Aquat. Sci. 45, 1744-57.

Jackson, T.A. (1991). Biological and environmental control of mercury accumulation by fish in lakes and reservoirs of northern Manitoba, Canada. Can. J. Fish Aquat. Sci. 48, 2448-70.

Jackson, T.A. (1998). Mercury in aquatic ecosystems. In W.J. Langston and M.J. Bebianno (eds). Metal metabolism in aquatic environments, pp. 77-158. London, Engl: Chapman and Hall.

Jackson, T.A. (2001). Variation in the isotope composition of mercury in a freshwater sediment sequence and food web. Can. J. Fish Aquat. Sci. 58, 185-96.

Johnston, T.A., Bodaly, R.A. and Mathias, J.A. (1991). Predicting fish mercury levels from physical characteristics of boreal reservoirs. Can. J. Fish Aquat. Sci. 48, 1468-75.

Lafrancois, B. and Carlisle, D.M. (2004). Mercury burdens and trophic position of Orconectes virilis in Voyageurs National Park. Bull. NA. Benthol. Soc. 21, 381-382.

Lucotte M., Schetagne R., Therien N., Langlois C. and Tremblay A. (eds). (1999). Mercury in the Biogeochemical Cycle: Natural Environments and Hydroelectric Reservoirs of Northern Quebec (Canada). Springer-Verlag, Berlin Germany 334.

Martin, S.M. (1997). Crayfishes (Crustacea: Decapoda) of Maine. Northeast Nat. 4, 165-88.

Mason, R.P., Laporte, J. and Andres, S. (2000). Factors controlling the bioaccumulation of mercury, methylmercury, arsenic, selenium, and cadmium by freshwater invertebrates and fish. Arch. Environ. Contam. Toxicol. 38, 283-97.

Matisoff, G. and Wang, X. (1998). Solute transport in sediments by freshwater infaunal bioirrigators. Limnol. Oceangr. 43, 1487-99.

McMurty, M.J., Wales, D.L., Scheider, W.A., Beggs, G.L. and Dimond, P.E. (1989). Relationship of mercury concentrations in lake trout (Salvelinus namaycush) and smallmouth bass (Micropterus dolomieui) to the physical and chemical characteristics of Ontario lakes. Can. J. Fish Aquatic. Sci. 46, 426-34.

McNicol, D.K., Mallory, M.L., Mierle, G., Scheuhammer, A.M. and Wong, A.H.K. (1997). Leeches as indicators of dietary mercury exposure in non-piscivorous waterfowl in central Ontario, Canada. Environ. Pollut. 95, 177-81.

Meili, M. (1991). The coupling of mercury and organic matter in the biogeochemical cycle: towards a mechanistic model for the boreal forest zone. Water Air Soil Pollut. 56, $333-47$. 
Odin, M., Feurtet-Mazel, A., Ribeyre, F. and Boudou, A. (1995). Temperature, $\mathrm{pH}$ and photoperiod effects on mercury bioaccumulation by nymphs of the burrowing mayfly Hexagenia rigida. Water Air Soil Pollut. 80, 1003-6.

Parkman, H. and Meili, M. (1993). Mercury in macroinvertebrates from Swedish forest lakes: influence of lake type, habitat, life cycle, and food quality. Can. J. Fish Aquat. Sci. 50, 521-34.

Parks, J.W. (1988). Selected ecosystem relationships in the mercury contaminated Wabigoon-English River system, Canada, and their underlying causes. Water Air Soil Pollut. 42, 267-79.

Parks, J.W., Curry, C., Romani, D. and Russell, D.D. (1991). Young northern pike, yellow perch and crayfish as bioindicators in a mercury contaminated watercourse. Environ. Monitor. Assess. 16, 39-73.

Parks, J.W. and Hamilton, A.L. (1987). Accelerating recovery of the mercury-contaminated Wabigoon/English River system. Hydrobiologia 149, 159-88.

Resh V.H. and Rosenberg D.M. (eds). (1984). The Ecology of Aquatic Insects. Praeger Publishers, New York, NY, USA 625.

Rogers, D.W. (1994). You are what you eat and a little bit more: bioenergetics-based models of methylmercury accumulation in fish revisited. In C.J. Watras and J.W. Huckabee (eds). Mercury pollution: integration and synthesis, pp. 427-39. Boca Raton, FL: Lewis Publishers.

Rincon, F., Zurera, G. and Pozo-Lora, R. (1987). Size and mercury concentration relationship as contamination index. Bull. Environ. Contam. Toxicol. 38, 515-22.

Scheuhammer, A.M. and Graham, J.E. (1999). The bioaccumulation of mercury in aquatic organisms from two similar lakes with differing pH. Ecotoxicology 8, 49-56.

Scott, D.P. and Armstrong, F.A.J. (1972). Mercury concentration in relation to size in several species of freshwater fishes from Manitoba and northwestern Ontario. J. Fish Res. Board Can. 29, 1685-90.

Scott, D.P. (1974). Mercury concentration in white muscle in relation to age, growth, and condition in four species of fish from Clay Lake, Ontario. J. Fish Res. Board Can. 31, 172329.

Simon, O. and Boudou, A. (2001). Simultaneous experimental study of direct and direct plus trophic contamination of the crayfish Astacus astacus by inorganic mercury and methylmercury. Environ. Toxicol. Chem. 20, 1206-15.

Simonin, H.A., Gloss, S.P., Driscoll, C.T., Schofield, C.L., Kretser, W.A., Karcher, R.W. and Symula, J. (1994). Mercury in yellow perch from Adirondack drainage lakes (New York U.S.). In C.J. Watras and J.W. Huckabee (eds). Mercury Pollution: Integration and Synthesis, pp. 457-69. Boca Raton, FL, USA: Lewis Publishers.

Spry, D.J. and Wiener, J.G. (1991). Metal bioavailability and toxicity to fish in low-alkalinity lakes: a critical review. Environ. Pollut. 71, 243-304.

Sterner, R.W. and Elser, J.J. (2002). Ecological Stoichiometry: The Biology of Elements from Molecules to the Biosphere. Princeton University Press, Princeton, NJ, USA 439.

Stinson, M.D. and Eaton, D.L. (1983). Concentrations of lead, cadmium, mercury, and copper in the crayfish (Pascifasticus leniusculus) obtained from a lake receiving urban runoff. Arch. Environ. Contam. Toxicol. 12, 693-700.

Suchanek, T.H., Richerson, P.J., Holts, L.J., Lamphere, B.A., Woodmansee, C.E., Slotton, D.G., Harner, E.J. and Woodward, L.A. (1995). Impacts of mercury on benthic invertebrate populations and communities within the aquatic ecosystem of Clear Lake, California. Water Air Soil Poll. 80, 951-60.

Tremblay, A. (1999). Bioaccumulation of mercury and methylmercury in invertebrates from natural boreal lakes. In M. Lucotte, R. Schetagne, N. Therien, C. Langlois and A. Tremblay (eds). Mercury in the Biogeochemical Cycle: Natural Environments and Hydroelectric Reservoirs of Northern Quebec (Canada), pp. 89-113. Berlin, Germany: Springer-Verlag.

Tremblay, A. and Lucotte, M. (1997). Accumulation of total and methyl mercury in insect larvae of hydroelectric reservoirs. Can. J. Fish Aquat. Sci. 54, 832-41.

Tremblay, A., Lucotte, M. and Rowan, D. (1995). Different factors related to mercury concentration in sediments and zooplankton of 73 Canadian lakes. Water Air Soil Poll. 80, 961-70.

Ullrich, S.M., Tanton, T.W. and Abdrashitova, S.A. (2001). Mercury in the aquatic environment: a review of factors affecting methylation. Crit. Rev. Environ. Sci. Tech. 31, 241-93.

Verneer, K. (1972). The crayfish Orconectes virilis, as an indicator of mercury contamination. Can. Field Nat. 86, 123-25.

Verta, M., Rekolainen, S., Mannio, J. and Surma-Aho, K. (1986). The Origin and Level of Mercury in Finnish Forest Lakes. Publication No. 65. Water Research Institute, National Board of Waters, Helsinki, Finland 21-31.

Wagemann, R., Trebacz, E., Hunt, R. and Boila, G. (1997). Percent methylmercury and organic mercury in tissues of marine mammals and fish using different experimental and calculation methods. Environ. Toxicol. Chem. 16, 1859-66.

Watras, C.J., Back, R.C., Halverson, S., Hudson, R.J.M., Morrison, K.A. and Wente, S.P. (1998). Bioaccumulation of mercury in pelagic freshwater food webs. Sci. Total Environ. 219, 183-208.

Wiener, J.G. and Spry, D.J. (1996). Toxicological significance of mercury in freshwater fish. In W.N. Beyer, G.H. Heinz and A.W. Redmon-Norwood (eds). Environmental Contaminants in Wildlife: Interpreting Tissue Concentrations, pp. 297-339. Boca Raton, FL, USA: Special Publications of SETAC Lewis Publishers.

Wong, A.H.K., McQueen, D.J., Williams, D.D. and Demers, E. (1997). Transfer of mercury from benthic invertebrates to fishes in lakes with contrasting fish community structures. Can. J. Fish Aquat. Sci. 54, 1320-30.

Wren, C.D., MacCrimmon, H.R. and Loescher, B.R. (1983). Examination of bioaccumulation and biomagnification of metals in a Precambrian Shield lake. Water Air Soil Poll. 19, 277-91.

Wright, D.A., Welbourn, P.M. and Martin, A.V.M. (1991). Inorganic and organic mercury uptake and loss by the crayfish Orconectes propinquus. Water Air Soil Poll. 56, 697-707. 